\title{
Critical Thinking in Language Education
}

\author{
Saeed Rezaei \\ Sharif University of Technology, Tehran, Iran \& Allameh Tabataba'i University, Tehran, Iran \\ Email: rezaei63@yahoo.com
}

Ali Derakhshan

Allameh Tabataba'i University, Tehran, Iran

Email: aderakhshanh@gmail.com

Marzieh Bagherkazemi

Allameh Tabataba'i University, Tehran, Iran

Email: Kazemi.marzieh62@gmail.com

\begin{abstract}
Critical thinking, rooted in critical philosophy, has long been an influential part and parcel of Western education. The present study is an attempt to sketch the concept of critical thinking as a viable cornerstone in language education. First, a number of the definitions of the concept as posited by different scholars are put forth. Second, the typical features of critical thinkers are introduced from the perspectives of education scholars. Third, different standpoints on the teachability of the ability to think critically are reviewed. And finally, a number of classroom techniques, including debates, media analyses, problemsolving tasks, self-assessment and peer-assessment, likely to foster critical thinking skills in language classrooms are proposed.
\end{abstract}

Index Terms — critical thinking, education, language

\section{INTRODUCTION}

Honing critical thinking skills in learners has been of significant research interest and one of the dominant research areas in educational contexts in various countries. Education psychologists, such as Thomas \&Smoot (1994) and Huitt (1998) have pronounced that critical thinking is a very important element of schooling in the $21^{\text {st }}$ century. Huitt (1998) stipulates that in the information age, thinking plays a significant role in one's success in life. He goes on to say that the movement toward the information age has shifted attention to good thinking as a significant element of life success. These changing conditions require new outcomes, such as critical thinking, to be embarked upon as a focus of schooling. Old standards of simply being able to score well on a standardized test of basic skills, though still appropriate, cannot be the sole criterion based on which to judge the academic success or failure of students.

In a similar vein, Chaffee (1985) and Paul (1995) mention that enhancing students' critical thinking abilities is the core of meaningful education. Chaffee (1985) explains that meaningful education halts students from involving in the unreflective learning of information, and equips them with the tools necessary to understand thoroughly the world they are in.

For a variety of reasons (Fok, 2002), some teachers believe that critical thinking cannot be taught, and some think that it does not need to be taught deliberately explicitly. Although some teachers support the idea of teaching students critical thinking abilities, they feel that they don't have the capacity or confidence to do it. In addition, contextual constraints such as those imposed by exam-oriented cultures and the heavy emphasis placed on the rote learning of facts and information to excel on tests may exert a harmful effect on the students' overall development including their development of creative and critical thinking abilities.

\section{CRITICAL THINKING DEFINED}

The past decade or so has witnessed the release and dissemination of a variety of books and articles on Critical Thinking. There is widespread consensus that the instruction of critical thinking is an all important issue standing in need of further research (Appleby, 2006; Halpern, 2002). However, psychologists and language methodologists have difficulty putting forward a precise and rigorous definition of critical thinking. That's why Halanon (1995) states that "critical thinking scholarship is in a mystified state. No single definition of critical thinking is widely accepted" (p. 75). Along the same lines, Minnich (1990) asserts that critical thinking is a "mystified concept" (p. 5). Fasko (2003), too, is aware of such indeterminacy when he asserts that 'there is no consensus on a definition of critical thinking' (p.8) in psychology, education or philosophy, and indeed the definitions of critical thinking have been changing (Huitt, 1998).

Siegel (1988) points out that 'despite widespread recent interest in critical thinking in education, there is no 
clear agreement concerning the referent of the term' (p.5), but he mentions that the notion of critical thinking has to be delineated with some precision for it to have significant impact on educational thinking and practice.

Reviewing the many definitions of critical thinking, Siegel (1988) identifies two rather different conceptions of critical thinking running through the related literature: the 'pure skills' (p.6) and the 'skills plus tendencies' (p.6) conceptions of critical thinking. According to Siegel, the 'pure skills' conception of critical thinking concentrates entirely upon a person's ability to assess correctly or evaluate certain sorts of statements. A person is a critical thinker, from this viewpoint, if she has the skills, abilities, or proficiencies necessary for the proper evaluation of statements. However, as Siegel (1988) illuminates, this conception is incomplete because it overlooks the salience of the actual utilization of these skills and abilities in a person's everyday life. The impact of this conception of critical thinking on the educational context could be less than promising if students drew upon critical thinking in tests only to get good grades in exams but not outside the testing context. Siegel (1988) argues that critical thinking needs something more than skills.

Siegel (1988) calls the second conception of critical thinking the 'skills plus tendencies' (p.6) conception, resting on the idea that "a critical thinker has both the skills or proficiencies necessary for the proper assessing of statements (and actions), and also the tendency to exercise those proficiencies in their ordinary statement- (and action-) assessing activities" (p.6). Following this view, a person is a critical thinker, if he or she is able and ready to think critically. As Siegel (1988) mentions this conception of critical thinking extends critical thinking beyond the skill of assessing statements and actions. There are also significant dispositions, values and traits that a critical thinker needs to develop.

[The second conception of critical thinking] concerns the characterization not simply of a set of cognitive skills or criteria of reasoning assessment, but more importantly of a certain sort of person. To recognize this is to recognize the depth of the concept of critical thinking, and the importance of character, values and other moral dimensions of the concept. (Siegel, 1988, p. 10)

Siegel (1988) goes on to propose the two central components of this conceptualization of critical thinking that would be particularly prominent in educational contexts. The first one is 'the ability to assess reasons properly which is referred to as the "reason assessment components" (p.23). The second one is the "critical attitude or critical spirit" (p.23) component of critical thinking. It is "the willingness, desire, and disposition to base one's actions and beliefs on reasons; that is to do reason assessment and be guided by the results of such assessment" (p.23). Siegel asserts that 'both components are essential to the proper conceptualization of critical thinking, possession of which is essential for the achievement of critical thinking by a person" (1988, p.23).

Some authors believe that these differences could partly be attributed to different terms used to offer an unequivocal definition of the concept of critical thinking. For example, Atkinson (1997) points out that a variety of definitions of critical thinking have been offered and that they differ to some degree. On the contrary, Davidson (1998) argues that if one scrutinizes these definitions, it is easy to notice large areas of overlap. The definitions are, in fact, often simply paraphrases of the same idea. They simply link critical thinking to rational judgment. Siegel (1988) calls critical thinking "the educational cognate of rationality" (p. 32). Alternatively, Lipman (1991) defines it as healthy skepticism, whereas Norris and Ennis (1989) call it "reasonable and reflective thinking that is focused upon deciding what to believe and do" (p. 3). Taking a similar path, Halpern (2003) defines critical thinking as "the use of those cognitive skills or strategies that increase the probability of a desirable outcome....thinking that is purposeful, reasoned, and goal oriented" (p.6). In like manner, Bensley (1998) defines it as "reflective thinking involving the evaluation of evidence relevant to a claim so that a sound conclusion can be drawn from the evidence" (p.5). Diestler (2001) believes critical thinking is "the use of specific criteria to evaluate reasoning and make decisions" (p.2). In a similar vein, Levy(1997) defines critical thinking as " an active and systematic cognitive strategy to examine, evaluate, understand events, solve problems, and make decisions on the basis of sound reasoning and valid evidence" (p. 236).

Paul (1985) also defines critical thinking as "learning how to ask and answer questions of analysis, synthesis, and evaluation" (p. 37). Along the same line of inquiry, Brookfield (1987) believes that critical thinking encompasses two interconnected processes, namely, "identifying and challenging assumptions, and imagining and exploring others" (p.229). Pithers and Soden (2000) agree that critical thinking involves a number of abilities such as identifying a problem and the assumptions on which it is based, focusing the problem, analyzing, understanding and making use of inferences, inductive and deductive logic, and judging the validity and reliability of assumptions and sources of data.

Critical thinking can also be described as the scientific method applied by ordinary people to the ordinary world (Schafersman, 1991). This is true since critical thinking is aligned with the well-known method of scientific investigation: a question is posed and a hypothesis formulated, germane data are sought and gathered, the hypothesis is further tested on the basis of the data, and conclusions are made at the end of the process. All the skills of scientific investigation map onto critical thinking abilities. So, critical thinking is scientific thinking.

Although all the above-mentioned definitions differ in scope and emphasis, they all place a premium on both the process and the outcome of learning. The ultimate objective for teaching critical thinking is to help students make correct judgments based on the careful weighing of available evidence. However, critical thinking is a very intricate endeavor. Buskist and Irons (2008) mention that such an enterprise requires students to learn several subtasks which include, among others: 
a. Developing a skeptical approach to problem solving and decision making;

b. Breaking down problems into their simplest outcomes;

c. Searching for evidence that both supports and refutes a given conclusion;

d. Maintaining a vigilant attitude toward their personal bias, assumptions, and values that may interfere with making an objective decision.

Still some other researchers (Atkinson, 1998; Benesch, 1993) emphasize the social and democratic aspects of critical thinking. They believe that social practice is one of the indispensable components of critical thinking. Atkinson (1998) strongly explicates that critical thinking is cultural thinking. However, he is dubious as to whether it can be taken for granted, and he further mentions that language educators should embark upon its adoption judiciously and cautiously. He states four reasons for this speculation:

Critical thinking may be more on the order of a non-overt social practice than a well-defined and teachable pedagogical set of behaviors; (b) critical thinking can be and has been criticized for its exclusive and reductive character; (c) teaching thinking to nonnative speakers may be fraught with cultural problems; and, (d) once having been taught, thinking skills do not appear to transfer effectively beyond their narrow contexts of instruction. (p. 71)

In like manner, Fox expresses concerns as to the cultural load of the concept of critical thinking:

This thing we call "critical thinking" or "analysis" has strong cultural components. It is more than just a set of writing and thinking techniques-it is a voice, a stance, a relationship with texts and family members, friends, teachers, the media, even the history of one's country. This is why "critical analysis" is so hard for faculty members to talk about; because it is learned intuitively it is easy to recognize, like a face or a personality, but it is not so easily defined and is not at all simple to explain to someone who has been brought up differently. (Fox, 1994, p. 125)

Benesch (1993) emphasizes that critical thinking is not simply higher order thinking; instead, it is a quest for the social, historical, and political roots of conventional knowledge and an orientation to transform learning and society (Brookfield, 1987; Shor \& Freire, 1987). Conversely, Davidson (1998) casts doubt on the social dimension of critical thinking. He criticizes Atkinson (1998) arguing that critical thinking appears to be something more universally relevant than just a social practice. If some cultures vary in their present ability to appropriate the tools of critical thinking, it is probably only a difference in the degree to which critical thinking is endured in certain parts of life. In any case, part of the task of the ESL/EFL teacher is to prepare students for the world outside their societies. There is even evidence that many students are ready for and in need of critical thinking abilities.

Viewing critical thinking as an inherently social and cultural concept, Oster (1989) concedes that social and cultural illuminations necessary to fully grasp its features. He admires the Western education system for its being open to a plurality of views, and encouraging originality and analysis, rather than memorization and quotation. He stipulates that if students are to enter an American or European university, they must be taught to think like the members of the target community, not to presume things to be universal when they are culture-sensitive, to feel free to express their thoughts and experiences and to find value in so doing. To these ends, he offers the study of the target language literature and its analysis as a safe and promising ground for developing critical thinking skills in foreign or second language learners.

\section{CRITICAL THINKERS AND THEIR CHARACTERISTIC FEATURES}

How would you know who a critical thinker is? Buskist and Irons (2008) felicitously assert that critical thinkers do not have "CT" tattooed on their foreheads, nor do they put on t-shirts labeled with "I'm a critical thinker". They demonstrate a welter of behaviors and skills that are quite conspicuous in situations requiring problem solving. A great body of literature (Bensley, 1998; Diesther, 2001; Fisher, 2001; Halpern, 2003; Levy, 1997; Birjandi \& Bagherkazemi, 2010) highlights that critical thinkers are those who, among other features:

- have a strong intention to recognize the importance of good thinking;

- identify problems and focus on relevant topics and issues;

- distinguish between valid and invalid inferences;

- suspend judgments and decisions in the absence of sufficient evidence;

- understand the difference between logical reasoning and rationalizing;

- be aware of the fact that one's understanding is limited and that there are degrees of belief;

- watch out for authoritarian influences and specious arguments;

- anticipate the consequences of alternative actions;

- accurately explain their decisions;

- consider alternative explanations for any state of affairs;

- curb their emotional reactions to others' arguments;

- determine the truth or falsity of assumptions;

- develop and present reasoned and persuasive arguments;

- distinguish between primary and secondary sources of information;

- distinguish credible from non-credible sources of information;

- differentiate evidence from opinion, common sense, anecdotes, and appeals to authority;

- distinguish opinions from facts; 
- draw inferences;

- formulate and ask appropriate questions;

- gather data from multiple sources relevant to a problem to be solved or a decision to be made;

- identify their preconceptions about important issues;

- understand the use and abuses of mathematical and statistical information in decision.

It needs to be emphasize that critical thinkers can also be characterized as enjoying the following features:

- they can listen attentively to others and provide them with appropriate feedback;

- they can assess and evaluate statements;

- they have a keen sense of curiosity;

- they have a strong proclivity to substantiate statements;

- they are open to criticisms;

- they are malleable;

- they can self-assess themselves

Undeniably, all such qualities are essential to what teachers reveal to students about their particular academic disciplines as well as to how students negotiate problems in everyday life. Surely, if there is one skill that college should hone in students, it is how to apply what they learn in their classes in their everyday life. Sadly, academic settings have put too much emphasis on "what to think" rather than "how to think". Schafersman (1991) mentions that we are really adroit at transmitting the content of what we teach to our students but often fail to teach them how to think critically and evaluate effectively. Children are not born with the power to think critically, nor do they develop this ability beyond survival-level thinking in the absence of implicit and explicit instruction. Critical thinking has to be learnt, so teachers are all called upon to enhance in learners the ability to think critically.

\section{CRITICAL THINKING: How TEACHABLE IS IT?}

Based upon the two conceptualizations of critical thinking, i.e. 'pure skills' and 'skills plus tendencies' (Siegel, 1988, p.6), approaches to the teaching of critical thinking can be of two types: (1) the teaching of critical thinking refers to teaching students trainable and assessable reasoning skills and processes, and (2) the teaching of critical thinking means teaching students those trainable and assessable reasoning skills as well as cultivating in them the dispositions and awareness associated with critical thinking. Engaging students actively in critical thinking processes through the effective use of teacher questions, discussion and reflection in a context that supports critical thinking and values inquiry, and teachers' practicing of critical thinking skills and attitudes and explicit explanations of the significance of critical thinking could help students to develop both the critical thinking skills and their associates critical attitudes.

In terms of language teaching, using provocative and inferential questions to ameliorate students' critical thinking in the teaching of reading and writing is not uncommon. Cook (1991), who regards reading primarily as a thinking process, emphasized the importance of engaging students in talking about the text they read. In like manner, Elder and Paul (2004), who consider critical thinking as the art of close reading, point out that 'to learn well, one must read well' (p.37). They emphasize the importance of engaging oneself in constant questioning in the reading process. Following Elder and Paul (2004), Paul (2005) states that 'a critical mind improves reading by reflectively thinking about what and how it reads' (p.32). Similarly, in terms of writing Elder and Paul (2005) point out that revision of drafts both cognitive and meta-cognitive thinking processes and thus writing could help enhance the students' critical thinking.

Regarding the teaching of critical thinking as the teaching of a set of generic reasoning skills, such as deductive and inductive reasoning, Solon (2003) conducted a controlled experimental study that aimed to investigate the impact of different critical thinking instruction approaches on the critical thinking test scores of community college students. The findings of the study revealed that 'different levels of treatment can lead to significantly different levels of improvement' and that 'the critical thinking course intervention had more impact than the infusion approach' (Solon, 2003, p.36). In the study, three groups of community college students reported to share similar educational backgrounds and different critical thinking abilities received different amounts of critical thinking instruction. The first group of students underwent a critical thinking course in which standard logic and reasoning were focused on. In the course, a great deal of class time was spent on argument analysis and small group discussion. Students were also required to keep a reflective journal of the weekly critique they made on the items that they selected from the mass media. The second group of students attended a psychology course in which about 25 percent of class time involved critical thinkingrelated instruction and activities. The students in this group were also required to complete some critical thinking assignments. Only some of these assignments were graded according to critical thinking principles. The last group of students was a control group, receiving no critical thinking instruction at all. Solon's (2003) study indicated that, regarding the teaching of critical thinking as some generic reasoning skills, it is important to engage students actively in different critical thinking processes, such as analysis of ideas, discussion and reflection through writing as well as making explicit to students the significance of critical thinking.

In a similar line of inquiry, Yuretich (2004), who viewed the teaching of critical thinking as the teaching of some higher order reasoning skills, such as, analysis, synthesis and evaluation, conducted an experimental study to find out the extent to which active learning strategies improve students' critical thinking in large introductory classes in an 
American university. Through active learning strategies, students were given opportunities to process and evaluate information through discussion with fellow students. Yuretich (2004) highlighted that giving students a critical thinking opportunity, for example, allowing them the time to pause, reflect on, analyze and discuss an issue in a context that supports and values critical thinking, is indeed the key to critical thinking education.

Higher-order reasoning or critical thinking can be woven into a large enrollment class, but their inclusion requires moving beyond the traditional lecture and exam mode. Active learning methods offer the best solution. When students really ponder a question, discuss it in groups, or explain their answers to others, they are more likely to use skills at the more advanced levels of Bloom's Taxonomy. (Yuretich, 2004, p.44)

Similarly, Elder and Paul (2003) point out that turning students into active questioners is an important part of critical thinking education. They concede that it is important for learners to keep asking questions in the learning process, stressing that 'to learn well is to question well' (p.36). In terms of meaningful learning, Elder and Paul put forth various question types for students to ponder upon during their learning process. They also encompass questions that motivate students to approach an issue from various different aspects and levels, such as inquiring into the purpose, information, interpretation, assumption and implication of an issue.

Deep questions drive thought beneath the surface of things, forcing you to deal with complexities.

1. Questions of purpose force you to define tasks.

2. Questions of information force you to look at your sources of information as well as assess the quality of information.

3. Questions of interpretation force you to examine how you are organizing or giving meaning to information.

4. Questions of assumption force you to examine what you are taking for granted.

5. Questions of implication force you to follow out where your thinking IS going,

6. Questions of point of view force you to examine your perspective and to consider other relevant viewpoints.

(Elder and Paul, 2003, p.36)

Upon the review of literature done, the arguments for teachers to capitalize on questioning to augment students' critical thinking are strong. However, Bourdillon and Storey (2002) cautioned that teacher questions have to be handled appropriately to avoid common questioning errors in the teaching context. For instance, students are given too little mediation and thinking time to respond to challenging questions. They are not given the opportunity to ask questions and to contribute to the classroom discourse. According to Bourdillon and Storey (2002), genuine communication should be targeted in class and students' ideas should be heard, respected and considered carefully. However, Smith (1990) states that students should be engaged in the critical thinking process based on respect rather than power or exploitation, stressing the importance of teachers in modeling and practicing critical thinking and critical attitudes in critical thinking education.

Children learn to think critically when they have the opportunities and reason to think in critical ways; when they see (or hear) other engage in critical thinking; and when they are admitted into arguments, challenges, and debates based on respect rather than power or exploitation. (Smith, 1990, p. 107)

Some educators have pronounced not only the need for students to actively participate in the critical thinking process, but also the need for students to be aware of what they are learning and why they are learning critical thinking (Bourdillon and Storey, 2002). In a similar line of inquiry, Mayfield (2001) emphasized the importance of this awareness in students' critical thinking development, pinpointing that teachers should make clear to students the processes that they are engaged in and the aims they hope to reach through critical thinking.

People already know how to do many complex kinds of thinking [ ... ] All of us developed our own way of solving problems, using "street smarts" and common sense or even trial and error. Yet what we already know can be substantially strengthened by conscious attention. (Mayfield, 2001, p.8)

As far as classroom teaching is concerned, Mayfield (2001) goes on to explicate that a possible way to raise students' awareness of critical thinking is to involve them explicitly in critical thinking opportunities and in dialogue with others so that they could contemplate upon their own thinking and be cognizant of their thinking processes through asking questions and discussion.

It has been suggested that for various reasons, teachers still draw on traditional teaching approaches in many local classrooms. They impart knowledge to their students and students are deprived of the opportunity to genuinely discuss and exchange ideas in the class.

The teachers were still influenced by the traditional way of teaching, that is, they were too conscientious in imparting knowledge to students and giving the correct answers and students were not given too much room for free discussion. At times, when they disagreed with the answers given by teachers, there was not enough time for them to discuss this difference. (Fok, 2002, p.88)

Fok (2002) points out that equipping students with some rudimentary ideas in differentiating facts from opinions, i.e. the 'pure skills' conception of critical thinking, is far from adequate for critical thinking education (Siegel, 1988, p.6). Instead students need to develop various critical thinking skills as well as critical attitudes so that they would be able to evaluate critically their own opinions and ask critical questions about the world they are in.

What is more important is to develop students' attitude as a critical thinker: that is, to evaluate their own 
opinions and to ask questions about their beliefs and judgments. This is the most important and the most difficult part. (Fok, 2002, p.90)

Buskist and Irons (2008) explicate different reasons for which teachers and students feel reluctant to think critically some of which are enumerated as follows:

a. The outcomes of reasoned decisions do not map onto their personal preferences. In other words, sometimes students desire to engage in a particular behavior overpowers their reasoning as to why such behavior may or may not be beneficial.

b. Some students are used to being told what to do and when to do it. This particularly applies to students who come from backgrounds in which other people (parents, teachers, coaches, and other authority figures) have made decisions for them. Thus from these students' perspective, there is no apparent reason to think critically when others do all the thinking for them.

c. Having other people make decisions relieves students of responsibility. This is on a par with the notion of just following orders: "Because somebody tells me what to do, and I do it, I should not be held accountable for my actions-I was just doing as I was told."

d. From a sociopolitical perspective, some students may think that their judgment is inferior to that of an authoritative figure. Many students come from backgrounds in which they are instructed to "obey authority," which implies that "I am not ready to make decisions on my own-I need to look to older, wiser, and more informed people to tell me what to do."

e. Some students are accustomed to learning the information by heart rather than thinking about it. Memorizing facts and figures takes time and effort, to be sure, but it does not require the uncertainty that goes with thinking.

f. Some students may undermine the consequences of their decisions. These students may have never had to encounter the genuine consequences of poor decision making before because somebody else has always been there to protect them from those consequences.

g. Some students don't have time to allocate to genuine critical thinking. In addition to carrying a full academic load, some students raise families and work in part-time or full-time jobs while working on their degrees. These students often believe that they don't have the time to take classes that require a lot of out-of-class work such as writing papers, preparing presentations, and other assignments that require thoughtful preparation and the integration of knowledge.

h. Some students lack the basic topical knowledge needed for critical thinking. They simply do not have the academic background (they lack basic foundational knowledge) to understand, let alone analyze, integrate, and apply the subject matter they are currently "learning."

Buskist and Irons (2008) go on to explain that just as students feel apathetic to think critically, teachers may intensify such avoidance by failing to implement critical thinking as part of their courses. Most college and university teachers are motivated to teach their students to think critically, but to do so is an arduous task and demands a great deal of accountability and commitment. Developing intellectually challenging activities, problem-based scenarios, and other rigorous assignments is a critical thinking task in its own right. Although many teachers are enthusiastic to defy the challenge, there are several reasons for which teachers do not feel like teaching students to think critically:

a. Academia can be a demanding and time-consuming profession that often requires a delicate balance of teaching, service, and research. When time is scarce, teaching preparation may focus on other, more pressing obligations.

b. Some teachers may shy away from teaching critical thinking because they cannot easily assess the consequences of their teaching efforts to show that they have been effective. As teachers, we often rely on grades as indicators that students have learned and that we have done our job. It is not as easy to assess critical thinking skills as to assess the typical course content, so one can't tell if students are learning the critical thinking skills we try to teach them.

c. Because students often loathe being coerced to think critically and teachers want to be admired by students, some teachers may sacrifice critical thinking in their classes in exchange for popularity.

d. Since some teachers are not critical thinkers themselves, nor do they know how to teach the skills of being critical, and they may not feel comfortable enough with their own skills to ask their students to think critically. Holding a master's degree or a Ph.D. does not guarantee that one can think critically.

In spite of these student-teacher obstacles to teaching critical thinking, teachers can learn to develop classroom environments conducive to critical thinking. Having enumerated different reasons for teachers and students' resistance to implementing critical thinking, Buskist and Irons (2008) put forth five main suggestions for teaching critical thinking:

a. For each and every core topic in your class, provide students with problems to analyze or solve. It doesn't matter whether you ask students to tackle these problems in or out of the class - the important thing is that they have the opportunity to think critically about them.

b. Guide students in the development of their critical thinking skills with handouts (either paper or electronic) containing information about critical thinking techniques that you have found particularly effective in your quest to solve problems and make informed decisions (e.g., explain what it means to "consider alternative explanations" or "weigh the evidence" or "determine the truth or falsity the assumptions").

c. Take time in class to apply these methodologies to your subject matter so that you can model effective critical thinking for your students. Your teaching should provide your students with the opportunity to see critical thinking in action through a role model-you! 
d. You should bring to class some of those everyday examples of critical thinking (or lack of critical thinking) that you've been collecting since before the academic term started. Make sure the examples are relevant to your subject matter.

e. Give your students plenty of opportunity to practice their developing critical thinking skills, including examinations and other graded assignments. If you don't test it, many students won't study it. Besides, it makes good sense to test students on those key elements of the course that you stress as important-in other words, you should put your money where your mouth is!

The authors of the present study propose a couple of techniques that effectively work in EFL/ESL milieus since they enjoy a high degree of universality and practicality. These techniques include debate, problem solving, selfassessment assignments, and peer assessment assignments.

\section{A. Debate/Forum/Discussion}

Since debates are versatile and consequential in the range of topics and the format, they can inspire students' enthusiasm to critically contemplate upon topics from different perspectives. The debates could perpetuate in the optimal outcomes provided that:

a. the topics are mainly controversial;

b. the topics are of relevance to the class and the subject matter;

c. the topics are interesting and motivating;

d. students know the discussion topics in advance;

e. students are given enough time to mull over the topic from different angles;

f. students have enough opportunities to express themselves freely and critically.

\section{B. Media Analysis}

Having been informed about the sociopolitical and cultural dimensions of critical thinking, the authors have found media analysis quite beneficial in that students' awareness can be easily raised about issues such as equality, discrimination, bias, censorship, marginalization, etc providing that the abovementioned benchmarks are taken into consideration.

\section{Problem Solving Tasks and Activities}

One of the distinguishing features of critical thinkers is to be able to raise questions and find pertinent answers for them on the basis of reliable evidence. The process of finding contingent resolutions is premised upon thinking critically. To do so successfully, students need to work in pairs and groups to describe the content of discussion, to define the problem, to personalize the problem, to discuss the problem and its alternative solutions, and finally to evaluate the whole process.

\section{Self-assessment \& Peer-assessment Assignments}

The substantial issue at hand is that teachers often overlook their students' potentialities and susceptibilities. If teachers continue to disregard learners' views and opinions, or suppress them without ever giving them the opportunity to express themselves, then they will not be able to train and use their thinking skills. So, one way to alleviate the problem is to engage them in carefully guided self- and peer-assessment. Students should be given a chance to assess not only themselves but also others to enhance their critical thinking ability.

\section{CONCLUSION}

Upon an in-depth review of the existing literature on critical thinking, it is highly recommended that teachers assist their students to become effective critical thinkers, i.e. to help them acquire both the critical thinking skills and critical attitudes to deal with the changes and challenges given rise to be the information age. In terms of classroom teaching, teachers' effective use of questions, involving students in discussions on challenging and motivating topics and different forms of reflection conducted on the basis of respect could engage students in meaningful critical thinking processes. Moreover, a context that supports and values inquiry and a teaching and learning atmosphere that respects different and sometimes competing viewpoints are crucial in facilitating students' critical thinking development. Such practical techniques as debates, problem-solving tasks, selfassessment and peer-assessment can also be helpful. Finally, teachers' own in-class application of critical thinking skills and attitudes, and providing explicit explanations of the importance of critical thinking could also help students enhance critical thinking.

\section{REFERENCES}

[1] Appleby, D. (2006). Defining, teaching, and assessing critical thinking in introductory psychology. In D. S. Dunn \& S. L. Chew (Eds.), Best practices for teaching introductory psychology (pp. 57-69). Mahwah, NJ: Lawrence Erlbaum Associates.

[2] Atkinson, D. (1997). A critical approach to critical thinking in TESOL. TESOL Quarterly, 31 (1), 79-95.

[3] Benesch, S. (1993). Critical thinking: A learning process for democracy. TESOL Quarterly, 27(3), 545-547.

[4] Bensley, D. A. (1998). Critical thinking in psychology: A unified skills approach. Pacific Grove, CA: Brooks/Cole. 
[5] Birjandi, P. \& Bagherkazemi, M. (2010). The relationship between Iranian EFL teachers' critical thinking ability and their professional success. ELT, 3(2), 135-145.

[6] Bourdillon, H., \& Storey, A. (2002). Aspects of Teaching and Learning in Secondary Schools: Perspectives on Practice. London: Routledge Falmer.

[7] Brookfield, S. (1987). Developing critical thinkers. Milton Keyes: Open University Press.

[8] Buskist, W. \& Irons G.J. (2008). Simple strategies for teaching your students to think critically. In D. S. Dunn, J. S. Halonen, and R. A. Smith(Ed), Teaching Critical Thinking in Psychology: A H and book of Best Practices (pp.49 -57). UK: Blackwell Publishing Ltd.

[9] Chaffee, J. (1985). Thinking critically. Boston: Houghton Miftlin Company.

[10] Cook, J. E. (1991). Critical reading? How? Why? Teaching PreK-8, 21(6), 23-24.

[11] Davidson, B.W. (1998). A case for critical thinking in the English language classroom. TESOL quarterly, 32 (1), $119-123$.

[12] Diestler, S. (2001). Becoming a critical thinker: A user friendly manual (3rd ed.). Upper Saddle River, NJ: Prentice-Hall.

[13] Elder, L., \& Paul, R. (2003). Critical thinking: Teaching students how to study and learn (Part IV). Journal of Developmental Education, 2 7( 1), 36-37.

[14] Elder, L., \& Paul, R. (2004). Critical thinking... and the art of close reading (part IV). Journal of Developmental Education, 28(2): 36-37.

[15] Fasko, D. (2003). Critical thinking: origins, historical development, future direction. In D. Fasko (Ed.), Critical thinking and reasoning: Current research, theory and practice (pp.3-20). Cresskill, NJ: Hampton Press.

[16] Fisher, A. (2001). Critical thinking: An introduction. New York: Cambridge University Press.

[17] Fok, S. C. (2002). Teaching critical thinking skills in a Hong Kong secondary school. Asia Pacific Education Review, $3(1), 83-91$.

[18] Fox, H. (1994). Listening to the world: Cultural issues in academic writing. Urbana, IL: National Council of Teachers of English.

[19] Graff, H. J. (2000). Teaching politically without political correctness. Radical Teacher, 59, 26-30.

[20] Halonen, J. S. (1995). Demystifying critical thinking. Teaching of Psychology, 22, 75-81.

[21] Halpern, D. F. (2002). Teaching for critical thinking: A four-part model to enhance thinking skills. In S. F. Davis \& W. Buskist (Eds.), The teaching of psychology: Essays in honor of Wilbert J. McKeachie and Charles L. Brewer (pp. 91-105). Mahwah, NJ: Lawrence Erlbaum Associates.

[22] Huitt, W. (1998). Critical thinking: An overview. Educational Psychology Interactive. Retrieved March, 2009, from http://chiron.valdostaedu/whuitt/col/cogsys/critthnk.html. [Revision of paper presented at the Critical Thinking Conference sponsored by Gordon College, Barnesville, GA, March, 1993.]

[23] Levy, D. A. (1997). Tools of critical thinking: Metathoughts for psychology. Boston: Allyn \& Bacon.

[24] Lipman, M. (1991). Thinking in education. Cambridge: Cambridge University Press.

[25] Mayfield, M. (2001). Thinking for yourself: Developing critical thinking skills through reading and writing. (5 $5^{\text {th }}$ ed.). London: Harcourt College.

[26] McDaniel, C.A. (2006). Critical literacy: A way of thinking, a way of life. New York: Peter Lang.

[27] Minnich, E. (1990). Transforming knowledge. Philadelphia: Temple University Press.

[28] Norris, S., \& Ennis, R. (1989). Evaluating critical thinking. Pacific Grove, CA: Thinking Press \& Software.

[29] Oster, J. (1989). Seeing with different eyes: Another view of literature in the ESL class. TESOL Quarterly, 23(1), 85-103.

[30] Paul, R. W. (1985). Bloom's taxonomy and critical thinking intervention. Educational Leadership, 42(8), 36-39.

[31] Paul, R. (2005). The state of critical thinking today. New Directions for Community Colleges, 130, 27-38.

[32] Pithers, R. T., \& Soden, R. (2000). Critical thinking in education: A review. Educational Research, 42, $237-249$.

[33] Schafersman. (1991). An introduction to critical thinking. Retrieved March 16, 2010 from: www.freeenquiry/criticalthinking.html

[34] Shor, I., \& Freire, P. (1987). A pedagogy for liberation: Dialogues on transforming education. South Hadley, MA: Bergin \& Garvey.

[35] Siegel, H. (1988). Educating reason: Rationality, critical thinking and education. New York: Routledge \& Metheun.

[36] Smith, F. (1990). To think. New York: Teachers College Press.

[37] Solon, T. (2003). Teaching critical thinking: The more, the better! The Community College Enterprise, 9(2), 25-38.

[38] Thomas, G., \& Smoot, G. (1994). Critical thinking: A vital work skill. Trust for Educational Leadership, 23 , 34-38.

[39] Yuretich, F. R. (2004). Encouraging critical thinking: Measuring skills in large introductory science classes. Journal of College Science Teaching, 33(3), 40-46.

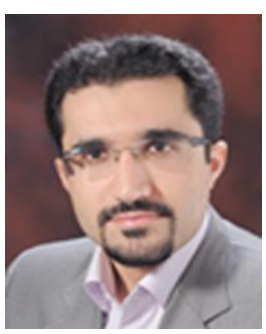

Saeed Rezaei is currently teaching at Sharif University of Technology and Allameh Tabataba'i University in Tehran. He is also a postgraduate student in TEFL at the department of English Language and Literature, Allameh Tabataba'i University (ATU), Tehran, Iran. He received his M.A. in TEFL from ATU and B.A. degree in English Language and Literature from Isfahan University, Isfahan, Iran.

He has presented several papers at ELT conferences held in Iran. He has also published some articles in international journals and authored some books.

His research interests include language education in Iran, SLA, Discourse Studies, L2 Identity, and Materials Development. 


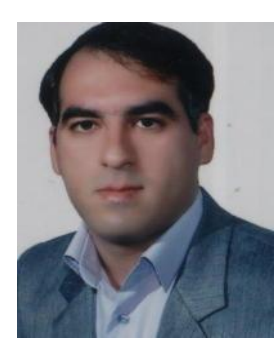

Ali Derakhshan is currently a $\mathrm{PhD}$ candidate majoring in Applied Linguistics at Allameh Tabataba' $\mathrm{i}$ University (ATU), Tehran, Iran. He received his M.A. in TEFL from University of Tehran, Iran. He is a visiting lecturer at Sharif University of Technology and Allameh Tabataba'i University (ATU). He was also opted the best national teacher in two consecutive years. He has coauthored 5 books and published some articles in international journals. His research interests are Language Assessment, Interlanguage Pragmatics Development \& Assessment, Syllabus Design, Teacher Education, Focus on Form/s, and MALL.

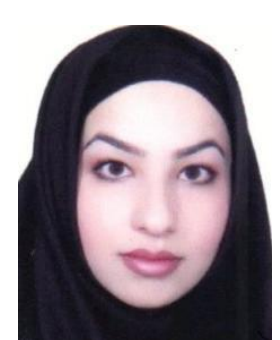

Marzieh Bagherkazemi was born in Iran in 1983. She has been a Ph.D. candidate of TEFL (Teaching English as a Foreign Language) at Allameh Tabataba'i University in Tehran, Iran since September 2009. She graduated B.A. in English literature and M.A. in TEFL both at Allameh Tabataba'i University in 2005 and 2008 respectively.

As for her professional background, she has taught English at a number of language schools, and tutored courses in IELTS, TOEFL and FCE since 2003. She has also been a lecturer, running General English, English Grammar and English Reading Comprehension courses at Allameh Tabataba'i and Islamic Azad universities in Tehran, Iran since 2008. Moreover, she has been involved in research on language learning, teaching and testing issues, and co-authored an Encyclopedia of Research Terms in Applied Linguistics (forthcoming), and a number of articles on the significance of "multiple intelligences" and "critical thinking" in language education, teaching literature, and also oral proficiency interviewing (in press). Her research interests include input and interaction in language learning, learner output, personality variables in language learning and teaching, issues in language teacher education, oral proficiency assessment, the role of UG in L2 acquisition, etc.

Ms. Bagherkazemi is currently a member of the editorial board of the Romanian journal LiBRI. Linguistic and Literary Broad Research and Innovation, and of the Teaching English Language and Literature Society of Iran (TELLSI). 